\title{
Changes in free and bound fractions of aroma compounds of four Vitis vinifera cultivars at the last ripening stages
}

\author{
Mar Vilanova $^{\mathrm{a}, *}$, Zlatina Genisheva ${ }^{\mathrm{b}}$, Lorenzo Bescansa ${ }^{\mathrm{c}}$, Antón Masa ${ }^{\mathrm{a}}$, José M. Oliveira ${ }^{\mathrm{b}}$ \\ ${ }^{a}$ Misión Biológica de Galicia (CSIC), Apartado de Correos 28, 38080 Pontevedra, Spain \\ ${ }^{\mathrm{b}}$ IBB - Institute for Biotechnology and Bioengineering, Centre of Biological Engineering, Universidade do Minho, 4710-057 Braga, Portugal \\ ${ }^{\mathrm{c}}$ Adega Lorenzo Bescansa S.U.L. Betanzos, Spain
}

\section{A R T I C L E I N F O}

\section{Article history:}

Received 29 August 2011

Received in revised form 10 October 2011

Available online 7 November 2011

\section{Keywords:}

Agudelo

Serradelo

Blanco lexitimo

Godello

Grapes

Ripening stages

Volatiles

Vitis vinifera

\begin{abstract}
A B S T R A C T
The volatile composition of white Agudelo, Blanco lexitimo, Godello and red Serradelo cultivars (NW Spain) harvested at two different stages of ripening have been evaluated. $\mathrm{C}_{6}$-compounds, alcohols, volatile fatty acids, monoterpenes, $\mathrm{C}_{13}$-norisoprenoids, volatile phenols and carbonyl compounds were identified and quantified in free and glycosidically bound forms by gas chromatography-mass spectrometry (GC-MS). The total volatile concentration showed a significant increase between the two ripening stages studied for all cultivars. The free volatile composition increased during maturity for Godello and Serradelo cultivars; however the glycosidically bound concentration increases for all cultivars with exception of $B$. lexitimo. Free $\mathrm{C}_{6}$-compounds ((E)-2-hexanal, 1-hexanol and (E)-2-hexen-1-ol) and bound alcohols (benzyl alcohol and 2-phenylethanol) showed the highest concentrations of volatile compounds for all grape cultivars in the two dates studied. Godello cultivar showed the highest change of volatile concentration between two ripening dates because of the high value of free $\mathrm{C}_{6}$-compounds. $B$. lexitimo was the most terpene-rich cultivar at the last ripening stage due to linalool; however $C_{13}$-norisoprenoids in free form were detected in low concentrations for all cultivars but not in Godello and B. lexitimo cultivars at the last ripening stage. Free hexanoic acid increased during ripening in all cultivars. The evolution of volatiles during ripening of grape juice from the cultivars studied was not proportional to the changes in sugar content, which shows that the technological and aromatic maturities did not occur at the same time in these cultivars. The results also showed the cultivar $*$ ripening date interaction for all, free and bound, groups of compounds.
\end{abstract}

(c) 2011 Elsevier Ltd. All rights reserved.

\section{Introduction}

Grape ripening is a physiological process that starts at the moment of véraison and lasts about 40 days, depending on the variety, environment and agricultural practices (Coello et al., 2007). This is a very important period that influences the composition of the grapes and, consequently, the wine, allowing grapes to develop their varietal characteristics (Gomez et al., 1995). The changes produced by the grapes during this period included physical changes (volume, weight, color and rigidity) and chemical changes $(\mathrm{pH}$, sugars, acidity, phenolics and volatile composition).

The volatile composition is one of the most important parameters responsible for wine quality and, hence, for consumer acceptance. Given the importance of the aroma on the quality of the wine it has been the subject of numerous studies. The chemical basis and the diversity of grape and wine odoriferous compounds have been reviewed in detail (Bayonove et al., 1998; Oliveira

\footnotetext{
* Corresponding author.

E-mail address: mvilanova@mbg.csic.es (M. Vilanova).
}

et al., 2000; Ribéreau-Gayon et al., 2000; Mateo and Jiménez, 2000; Swiegers and Pretorius, 2005).

The aroma of a grape must derive from aromatic free volatiles and from non-volatile, odorless precursors, which may be revealed during the winemaking process (Arevalo et al., 2006). Several families of compounds are responsible for primary aroma of grapes such as monoterpenols, abundant in Muscat varieties, methoxypyrazines, which characterize the Cabernet family, $\mathrm{C}_{13}$-norisoprenoids, abundant in Chardonnay, volatile thiols in Sauvignon, volatile phenols in Traminer aromatico, and dimethyl sulfide in Syrah. These compounds, however, could also contribute significantly to the aroma of several other varieties (Versini, 1985; Allen et al., 1991; Sefton et al., 1993; Tominaga et al., 2000; Segurel et al., 2004, 2005).

Most grape aroma compounds are present as free volatiles, which may contribute directly to odor, or as bound sugar conjugates, which are nonvolatile. Conjugates (including glycosides) can undergo acid or enzyme hydrolysis, releasing free volatiles and potentially enhancing aroma (Cordonnier and Bayonove, 1974; Zoecklein et al., 1997). Initial research on grape glycosides 
focused on monoterpenes and determined their role as aroma/flavor components of floral varieties. Subsequent research demonstrated the role of $\mathrm{C}_{13}$-norisoprenoid compounds and shikimic acid-derived metabolites as precursors of nonfloral grape aroma/ flavor (Williams et al., 1989).

Most of the volatile flavor components are produced after veraison until harvest. However notable aroma compounds that are produced during the first period of growth, decline during fruit ripening (Hardy, 1970; Hashizume and Samuta, 1999; Belancic and Agosin, 2007). $\mathrm{C}_{6}$-aldehydes and alcohols are formed from linoleic acid and linolenic acid when grapes enter into contact with the air, and are formed by the actions of lipoxygenase, peroxidase and alcohol dehydrogenase enzymes (Garcia et al., 2003). $\mathrm{C}_{13}$-norisoprenoid and terpene compounds are generated from carotenoids such as lutein and $\beta$-carotene (Winterhalter et al., 1990; Cox et al., 2005; Camara et al., 2004). Terpenes are important compounds as varietal aromas with floral and fruity notes and are present in green berries only in very small amounts, but their concentrations gradually rise during ripening until around maturity, after which concentrations fall (Wilson et al., 1984; Günata et al., 1985).

The concentration of varietal aroma compounds in grapes is influenced by several factors such as grape variety and degree of maturity, vintage, climate or vineyard management techniques (Bueno et al., 2003; Oliveira et al., 2006; Genisheva and Oliveira, 2009; Belancic and Agosin, 2007; Vilanova et al., 2007). It is generally recognized that grape maturity will affect the flavor profile parallel to the sugar content, however it is well accepted that aromatic maturity is achieved before technological maturity (Bayonove and Cordonnier, 1971; Marais, 1983; Marais and van Wyk, 1986). The knowledge of the grape varietal volatile composition offers a means of evaluating the aroma potential, and the period of time that the maximum potential is exhibited (Coello et al., 2007). Therefore it is important to determine the concentrations of varietal volatiles (terpenes, $\mathrm{C}_{13}$-norisoprenoids and $\mathrm{C}_{6}$-compounds) as a criterion to define the date of harvest (Salinas et al., 2004).

Betanzos is a geographical denomination of wines from NW Spain, where are grown several white cultivars such as Godello, Agudelo, Blanco lexitimo and red cultivars such as Serradelo. Previous work performed in our laboratory (Vilanova et al., 2009) reported a first study on the volatile composition of wines produced with these cultivars from Betanzos.

In this study, the determination of volatile compounds has been performed on cultivars from Betanzos (B. lexitimo, Agudelo, Godello and Serradelo) in the last ripening stages. The aims were to:

- Know the aromatic maturity of grapes and their relation with the technologic maturity (sugar content).

- Evaluate the significance of changes produced in the last stages of ripening to recognize the importance of volatile composition on the harvest date decision.

- Know the aroma potential of each cultivar and evaluate the period of time that the maximum potential is exhibited.

\section{Results and discussion}

\subsection{Changes in classic parameters during berry maturity}

Analytical results (Table 1 ) revealed differences in the dynamics of ripening in the four grape varieties considered in this study. White cultivars B. lexitimo and Godello displayed high sugar accumulation rates and attained maturity levels suitable for quality wines production in the last ripening stage (30 August). By contrast, the red Serradelo showed less maturity at the same date, followed by the white Agudelo cultivar. B. lexitimo showed the largest increase $\left(2.2^{\circ} \mathrm{Brix}\right)$ in sugar concentration during the ripening stages studied. These results were in accord with those observed in previous studies on wines where the higher ethanol concentration was obtained for B. lexitimo wines in contrast to Agudelo and Serradelo wines (Vilanova et al., 2009).

\subsection{Volatile composition of grapes}

The aroma is one of the main factors related to the quality of white wines and compounds responsible for wine aroma should be taken in account in the evaluation of the optimal stage of grape ripening (Sánchez Palomo et al., 2007). Fig. 1 shows the total volatile composition of grape cultivars from Betanzos during the last ripening stages. Godello cultivar showed the highest increase of volatiles between the two ripening dates, however $B$. lexitimo showed an opposite behavior to Godello. Other authors have shown that the results for a given harvest may be strongly influenced by weather conditions during ripening and that the results for volatile composition varied independently of sugar content (Marais et al., 1992; Dieguez et al., 2003).

\subsubsection{Free volatile compounds}

Table 2 shows the evolution of groups of free volatile compounds (means and standard deviations) during ripening stages, together with the ANOVA results for the factors "cultivar (C)" and "ripening date (D)" and interaction $\mathrm{C} * \mathrm{D}$. The total concentration of each group of compounds in free fraction was obtained as the sum of individual concentrations of all compounds detected under the experimental conditions used. This study includes 36 free volatile compounds: 9 alcohols, $6 \mathrm{C}_{6}$-compounds, 6 volatile fatty acids, 8 monoterpenes, $2 \mathrm{C}_{13}$-norisoprenoids, 4 volatile phenols and 1 carbonyl compounds (Table 3 ). Analysis of variance (ANOVA) by groups shows statistically significant differences among cultivars for all groups of free volatile compounds studied. The differences between the two ripening dates also were significant for all groups of free volatile compounds except for monoterpenes, where only B. lexitimo shows significant differences in monoterpenes among ripening stages. The variation of the total free volatile concentration was only significant between the two ripening dates for Godello $(p<0.001)$ and Serradelo $(p<0.05)$ cultivars. Godello showed the highest aromatic ripening at harvest date $(3.610 \mathrm{mg} /$ $\mathrm{L}$ ). The free volatile composition and the evolution of each group

Table 1

Characteristic of cultivars and grape juice during ripening.

\begin{tabular}{|c|c|c|c|c|c|c|c|c|}
\hline \multirow[t]{3}{*}{ Cultivars } & \multirow[t]{3}{*}{ Color } & \multirow[t]{3}{*}{ Training system } & \multicolumn{6}{|c|}{ Ripening date } \\
\hline & & & \multicolumn{3}{|c|}{ 23.08.2007 } & \multicolumn{3}{|c|}{ 30.08.2007 } \\
\hline & & & ${ }^{\circ}$ Brix & Sugar (g/L) & Total acidity (g/L) & ${ }^{\circ}$ Brix & Sugar (g/L) & Total acidity $(\mathrm{g} / \mathrm{L})$ \\
\hline Agudelo & White & Single cordon & 19.2 & 184 & 7.5 & 20.6 & 200 & 6.2 \\
\hline Godello & White & Single cordon & 19.6 & 188 & 8.5 & 21.0 & 204 & 7.1 \\
\hline Blanco lexitimo & White & Single cordon & 20.0 & 193 & 7.8 & 22.2 & 217 & 6.1 \\
\hline Serradelo & Red & Single cordon & 18.0 & 171 & 6.6 & 19.6 & 188 & 5.3 \\
\hline
\end{tabular}




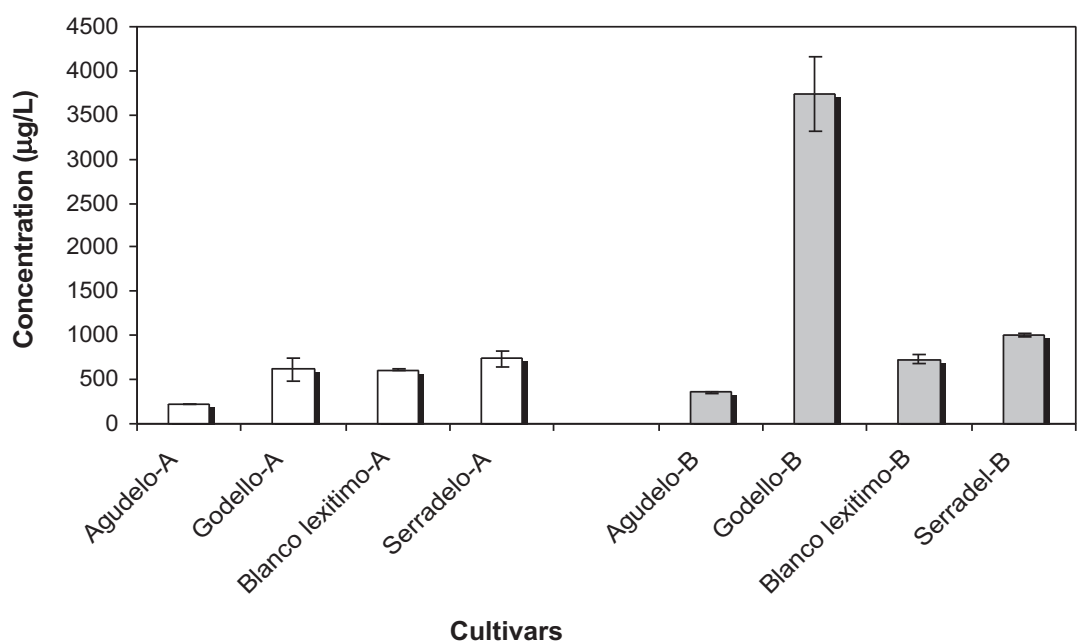

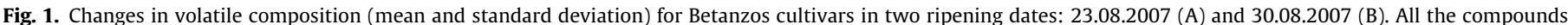
were quantified as 4-nonanol equivalents.

Table 2

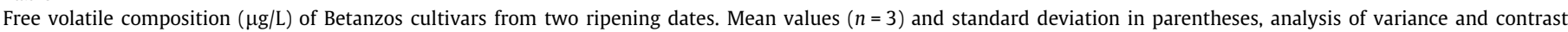
significance.

\begin{tabular}{|c|c|c|c|c|c|c|c|c|}
\hline Cultivar & Alcohols & $\mathrm{C}_{6}$-compounds & Monoterpenes & $\begin{array}{l}\mathrm{C}_{13^{-}} \\
\text {norisoprenoids }\end{array}$ & $\begin{array}{l}\text { Volatile } \\
\text { fatty } \\
\text { acids }\end{array}$ & $\begin{array}{l}\text { Volatile } \\
\text { phenols }\end{array}$ & $\begin{array}{l}\text { Carbonyl } \\
\text { compounds }\end{array}$ & Total \\
\hline \multicolumn{9}{|l|}{$\begin{array}{l}\text { Mean (SD) of free volatile compounds } \\
\text { Ripening date } 23.06 .2007 \text { (A) }\end{array}$} \\
\hline Agudelo & $3.0(0.0) \mathrm{a}$ & $146.5(1.2) \mathrm{a}$ & $2.5(0.1) b$ & $0.3(0.0) b$ & $1.5(0.3) \mathrm{a}$ & $0.9(0.6) \mathrm{a}$ & $0.4(0.0) \mathrm{a}$ & $155.1(0.4) \mathrm{a}$ \\
\hline Godello & $6.0(0.1) b$ & 572.1 (139.9) b & $1.1(0.1) \mathrm{a}$ & $0.2(0.0) \mathrm{b}$ & $3.0(0.6) \mathrm{a}$ & $2.1(0.1) b$ & $0.3(0.0) \mathrm{b}$ & $584.8(124.5) \mathrm{b}$ \\
\hline Blanco lexitimo & $3.1(0.3) \mathrm{a}$ & $522.3(2.5) \mathrm{b}$ & $22.5(0.9) c$ & nd a & $1.4(0.5) \mathrm{a}$ & $10.0(0.9) \mathrm{c}$ & nd $\mathrm{c}$ & $559.2(6.9) \mathrm{b}$ \\
\hline Serradelo & $6.2(1.3) \mathrm{b}$ & $619.8(100.40) b$ & $2.4(0.0) \mathrm{b}$ & $0.7(0.0) \mathrm{c}$ & $6.4(1.8) b$ & $7.6(0.0) \mathrm{d}$ & $0.3(0.1) b$ & $643.3(86.7) b$ \\
\hline \multicolumn{9}{|l|}{ Ripening date 30.08.2007 (B) } \\
\hline Agudelo & $5.7(0.2) \mathrm{a}$ & $200.2(1.2) \mathrm{a}$ & $3.1(0.1) \mathrm{a}$ & $0.4(0.1) b$ & $12.1(0.1) b$ & $2.4(0.4) b$ & $0.7(0.0) b$ & $224.5(0.2) \mathrm{a}$ \\
\hline Godello & $10.8(3.6) b$ & $\begin{array}{l}3595.3(1104.7) \\
\text { c }\end{array}$ & nd a & nd a & $1.8(0.7) \mathrm{a}$ & $1.5(0.1) \mathrm{a}$ & $1.3(0.1) \mathrm{c}$ & $\begin{array}{l}3610.8(407.2) \\
\text { c }\end{array}$ \\
\hline Blanco lexitimo & $9.9(0.1) b$ & $637.8(80.6) \mathrm{b}$ & $28.0(5.2) \mathrm{b}$ & nd a & $3.9(3.2) \mathrm{a}$ & $3.1(0.4) c$ & $0.6(0.1) b$ & $683.3(51.8) \mathrm{b}$ \\
\hline Serradelo & $4.9(0.4)$ a & $917.8(17.6) \mathrm{b}$ & $2.1(0.1) \mathrm{a}$ & $0.2(0.0) c$ & $9.6(3.9) \mathrm{b}$ & $3.1(0.2) \mathrm{c}$ & $0.3(0.1) \mathrm{a}$ & $938.0(13.1) b$ \\
\hline \multicolumn{9}{|l|}{ Analysis of variance p-values } \\
\hline Cultivar & 0.001 & $<0.0001$ & $<0.0001$ & $<0.0001$ & $<0.0001$ & $<0.0001$ & $<0.0001$ & $<0.0001$ \\
\hline Repetition & 0.226 & 0.655 & 0.519 & 0.979 & 0.049 & 0.442 & 0.959 & 0.627 \\
\hline Harvest date & $<0.0001$ & $<0.0001$ & 0.162 & $<0.0001$ & $<0.0001$ & $<0.0001$ & $<0.0001$ & $<0.0001$ \\
\hline Cultivar $*$ ripening date & 0.001 & $<0.0001$ & 0.041 & $<0.0001$ & 0.000 & $<0.0001$ & $<0.0001$ & $<0.0001$ \\
\hline \multicolumn{9}{|c|}{ Contrast p-values cultivar vs. ripening date } \\
\hline Agudelo-A vs. Agudelo-B & 0.026 & 0.686 & 0.738 & 0.012 & $<0.0001$ & 0.001 & $<0.0001$ & 0.604 \\
\hline Godello-A vs. Godello-B & $<0.001$ & $<0.0001$ & 0.487 & $<0.0001$ & 0.039 & 0.130 & $<0.0001$ & $<0.0001$ \\
\hline $\begin{array}{l}\text { Blanco lexitimo-A vs. Blanco lexitimo- } \\
\text { B }\end{array}$ & 0.001 & 0.389 & 0.003 & 1.000 & 0.080 & $<0.0001$ & $<0.0001$ & 0.357 \\
\hline Serradelo-A vs. Serradelo-B & 0.261 & 0.038 & 0.861 & $<0.0001$ & 0.031 & 0.0001 & 0.143 & 0.041 \\
\hline
\end{tabular}

nd - Not detected. Duncan test: different letters indicates significant differences among cultivars. All the compounds were quantified as 4-nonanol equivalents.

of volatiles was different for cultivars from Betanzos during grape ripening, showing interaction cultivar $*$ ripening.

The $\mathrm{C}_{6}$-compounds group, which showed the highest concentration of free volatile compounds in the two ripening dates for all cultivars, accounted for 90\% (Agudelo) and 99\% (Godello). Three compounds, (E)-2-hexenal, 1-hexanol and (E)-2-hexen-1-ol, had the highest values in all varieties studied. $\mathrm{C}_{6}$-compounds are related to varietal origin because they can be formed, via $\mathrm{C}_{6}$-aldehydes, through lipoxygenase activity, from linoleic and linolenic acids present in grapes (Oliveira et al., 2006; Cabaroglu et al., 1997; Moio et al., 2004; Kalua and Boss, 2009). C $_{6}$-compounds such as 1-hexanol and $(Z)$ and $(E)$-3-hexen-1-ol are sometimes at a rather high level as in the Müller-Thurgau wines, wherein these compounds has been suggested as a parameter for discrimination of this cultivar (Nicolini et al., 1996). In contrast we can see (Table 2 ) that the influence of ripening date on the free $\mathrm{C}_{6}$-compounds group was only significant for Godello $(p<0.001)$ and Serradelo $(p<0.05)$ cultivars. Godello cultivar showed a significant increase of $83.7 \%$ between the two ripening dates mainly due to two compounds (E)-2-hexanal and (E)-2-hexen-1-ol (Table 3). This behavior was not the same for all cultivars showing a cultivar $*$ ripening date effect for these compounds. Only one compound of this group, ( $Z$ )-2-hexen-1-ol, did not show significant differences between the two ripening stages for the cultivars studied. During ripening period, the concentration of these $\mathrm{C}_{6}$-alcohols tended to increase, stabilize, and then even decrease in the Airén variety from La Mancha region (Spain) at $9{ }^{\circ}$ Baumé to $11^{\circ}$ Baumé and in Macabeo and Chardonnay varieties at $11{ }^{\circ}$ Baumé to 
Table 3

Changes in free volatile composition of Betanzos grape cultivars during ripening.

\begin{tabular}{|c|c|c|c|c|c|c|c|c|c|c|c|}
\hline \multirow[t]{3}{*}{ Free compounds $(\mu \mathrm{g} / \mathrm{L})$} & \multicolumn{8}{|c|}{ Ripening date } & \multirow{2}{*}{\multicolumn{3}{|c|}{ ANOVA }} \\
\hline & \multicolumn{4}{|c|}{$23.08 .2007(\mathrm{~A})$} & \multicolumn{4}{|c|}{30.08 .2007 (B) } & & & \\
\hline & Agudelo & Godello & B. lexitimo & Serradelo & Agudelo & Godello & B. lexitimo & Serradelo & $\mathrm{C}$ & $\mathrm{D}$ & $\mathrm{C} * \mathrm{D}$ \\
\hline \multicolumn{12}{|l|}{ Monoterpenes } \\
\hline trans-Pyran linalool oxide & 0.56 & 0.29 & 11.34 & 0.89 & 0.35 & nd & 10.26 & 0.97 & $* * *$ & ns & ns \\
\hline cis-Pyran linalool oxide & 0.31 & 0.09 & 4.75 & nd & 0.31 & nd & 3.46 & nd & $* *$ & ns & ${ }^{* *}$ \\
\hline trans-Furan linalool oxide & nd & nd & nd & nd & nd & nd & 0.37 & nd & $* * *$ & $* * *$ & $* * *$ \\
\hline cis-Furan linalool oxide & nd & nd & nd & nd & nd & nd & 0.43 & nd & $* * *$ & $* * *$ & $* * *$ \\
\hline Geraniol & nd & nd & nd & nd & 0.47 & nd & nd & nd & $* * *$ & $* * *$ & $* * *$ \\
\hline$\alpha$-Terpineol & 0.96 & 0.56 & 1.77 & 0.72 & 0.18 & nd & 0.33 & 0.13 & $* * *$ & $* * *$ & $* * *$ \\
\hline Linalool & nd & 0.06 & 1.26 & nd & 0.12 & nd & 9.22 & nd & $* * *$ & $* * *$ & $* * *$ \\
\hline 3,7-Dimethylocta-1,5-dien-3,7-diol & 0.72 & 0.11 & 3.43 & 0.76 & 1.64 & nd & 3.94 & 0.99 & $* * *$ & ns & ns \\
\hline $\begin{array}{l}C_{13} \text {-norisoprenoids } \\
\beta \text {-Damascenone } \\
\beta \text {-Ionone }\end{array}$ & $\begin{array}{l}0.27 \\
\text { nd }\end{array}$ & $\begin{array}{l}\text { nd } \\
0.21\end{array}$ & $\begin{array}{l}\text { nd } \\
\text { nd }\end{array}$ & $\begin{array}{l}0.30 \\
0.36\end{array}$ & $\begin{array}{l}0.10 \\
0.26\end{array}$ & $\begin{array}{l}\text { nd } \\
\text { nd }\end{array}$ & $\begin{array}{l}\text { nd } \\
\text { nd }\end{array}$ & $\begin{array}{l}\text { nd } \\
0.19\end{array}$ & $\begin{array}{l}* * * \\
* * *\end{array}$ & $\begin{array}{l}* * * * \\
* *\end{array}$ & $\begin{array}{l}* * * \\
* * *\end{array}$ \\
\hline \multicolumn{12}{|l|}{$C_{6}$ compounds } \\
\hline 1-Hexanol & 84.52 & 121.47 & 137.50 & 338.41 & 67.85 & 409.47 & 145.30 & 537.78 & $* * *$ & $* * *$ & $* * *$ \\
\hline (E)-3-Hexen-1-ol & 1.20 & 4.86 & 4.05 & 1.63 & 0.88 & 64.42 & 3.23 & 4.10 & $* * *$ & $* * *$ & $* * *$ \\
\hline (Z)-3-Hexen-1-ol & 29.10 & 11.36 & 41.62 & 45.27 & 19.70 & 100.71 & 26.48 & 19.03 & $* * *$ & $*$ & ${ }^{* * *}$ \\
\hline (E)-2-Hexen-1-ol & 0.30 & 144.59 & 214.19 & 97.93 & 81.31 & 1324.94 & 358.65 & 241.78 & $* * *$ & $* * *$ & $* * *$ \\
\hline (Z)-2-Hexen-1-ol & 8.22 & 0.96 & 1.70 & nd & 0.27 & 9.82 & 1.70 & 0.86 & $* * *$ & ns & $* * *$ \\
\hline \multicolumn{12}{|l|}{ Alcohols } \\
\hline 2-Pentanol & 0.65 & 0.58 & nd & 0.93 & 0.41 & nd & 0.34 & 1.52 & $* * *$ & ns & $* * *$ \\
\hline 1-Butanol & nd & nd & nd & nd & 0.45 & nd & 0.45 & nd & $* * *$ & $* * * *$ & $* * *$ \\
\hline 1-Penten-3-ol & nd & 2.12 & nd & 2.27 & nd & nd & 2.95 & 2.00 & $* * *$ & ns & $* * *$ \\
\hline E-2-Penten-1-ol & 1.12 & 1.94 & 1.95 & 1.73 & 1.10 & 10.85 & 2.26 & nd & $* *$ & ${ }_{* *}^{* *}$ & $* * *$ \\
\hline 1-Octen-3-ol & nd & 0.32 & nd & 0.30 & 0.44 & nd & 0.24 & 0.39 & $* * *$ & $* * *$ & $* * *$ \\
\hline 1-Octanol & 0.38 & 0.38 & nd & 0.32 & 0.12 & nd & 0.10 & nd & $* * *$ & $* * *$ & $* * *$ \\
\hline Benzyl alcohol & 0.33 & 0.23 & nd & 0.30 & 0.25 & nd & 0.76 & 0.52 & $* * *$ & $* * *$ & $* * *$ \\
\hline 2-Phenylethanol & 0.55 & 0.28 & 1.12 & 0.32 & 2.17 & nd & 1.78 & 0.51 & $* * *$ & $* * *$ & $* * *$ \\
\hline 2-Phenoxyethanol & nd & 0.19 & nd & nd & 0.74 & nd & 1.01 & nd & $* * *$ & $* * *$ & $* * *$ \\
\hline \multicolumn{12}{|l|}{ Volatile fatty acids } \\
\hline Hexanoic acid & 1.03 & 1.35 & 1.39 & 1.55 & 3.86 & 1.83 & 2.57 & 5.50 & ns & $* * *$ & ns \\
\hline (E)-2-Hexenoic acid & nd & nd & nd & nd & 0.93 & nd & nd & nd & ${ }_{* * *}$ & $* * *$ & **** \\
\hline Octanoic acid & nd & nd & nd & nd & 3.74 & nd & 1.37 & 0.64 & $* * *$ & $* * *$ & $* * *$ \\
\hline Nonanoic acid & 0.52 & 0.16 & nd & nd & 1.20 & nd & nd & nd & $* * *$ & $* * *$ & $* * *$ \\
\hline Decanoic acid & nd & nd & nd & nd & 2.35 & nd & nd & 0.29 & $* * *$ & $* * *$ & $* * *$ \\
\hline Hexadecanóic acid & nd & 1.50 & nd & 4.82 & nd & nd & nd & 3.19 & $* * *$ & * & ns \\
\hline \multicolumn{12}{|l|}{ Volatile phenols } \\
\hline Methyl salicilate & nd & 1.53 & nd & 0.26 & 0.15 & 1.53 & 1.21 & 0.63 & $* * *$ & $* * *$ & $* * *$ \\
\hline 4-Vinylguaiacol & 0.86 & 0.13 & 3.43 & 0.36 & 0.23 & nd & nd & nd & $* * *$ & $* * *$ & $* * *$ \\
\hline Vanillin & nd & 0.43 & 6.53 & 6.94 & 1.67 & nd & 1.93 & 2.27 & $* * *$ & $* * *$ & $* * *$ \\
\hline Methyl vanilate & nd & nd & nd & nd & 0.36 & nd & nd & 0.24 & $* * *$ & **** & $* * *$ \\
\hline \multicolumn{12}{|l|}{ Carbonyl compounds } \\
\hline Benzaldehyde & 0.42 & 0.29 & nd & 0.32 & 0.70 & 1.30 & 0.59 & 0.25 & $* * *$ & $* * *$ & $* * *$ \\
\hline
\end{tabular}

C: cultivar; D: harvest date; ns: not significance; nd: not detected. All the compounds were quantified as 4-nonanol equivalents.

Significance at $95 \%$ level.

*** Significance at $99 \%$ level.

Significance at $99.9 \%$ level.

13 'Baumé (Garcia et al., 2003). (E)-2-Hexenal was the most abundant volatile compound in Riesling grapes, and it showed a significant increase in concentration after véraison until harvest (Kalua and Boss, 2010).

On the other hand, monoterpenes and $\mathrm{C}_{13}$-norisoprenoids are considered to be very important in determining the flavor and varietal character of Vitis vinifera cultivars and this concentration in wine may be increased by appropriate winemaking procedures (Rocha et al., 2007; Gomez et al., 1995; Garcia et al., 2003). With regard to the total concentration of free monoterpenes, $B$. lexitimo cultivar was the richest in the two ripening dates studied and the concentration increased during ripening due to linalool. Monoterpenes are the source of the characteristic floral and fruity characteristics of wines made from grape varieties such Muscat and Gewürztraminer, and to a lesser extent, of wines made from Riesling, Albariño/Alvarinho and Loureiro (Wilson et al., 1986; Versini et al., 1994; Muñoz-Organero et al., 1998; Bureau et al., 2000a,b;
Oliveira et al., 2008). Muscat/floral grape varieties may generally synthesize more terpenes than the non-Muscat/nonfloral grape varieties during ripening (Kalua and Boss, 2009). The concentration of these compounds gradually rises during ripening until maturity (Wilson et al., 1984; Günata et al., 1985). However terpenes may decrease once optimal sugar levels are attained, although this may be influenced by temperature and water availability during ripening (Ribéreau-Gayon et al., 2000). In Godello cultivar free monoterpenes were not detected at last ripening date and geraniol was only found in Agudelo cultivar at the same date. Geraniol was the most abundant monoterpene in Alvarinho (45.7\%) from the north of Portugal, followed by linalool (19.5\%) and then by transpyran linalool oxide (10.9\%) (Oliveira et al., 2004; Genisheva and Oliveira, 2009). However concentrations of the main free terpenols increased during grape development of Muscat Hamburg, except for geraniol (Fenoll et al., 2009). 3,7-Dimethyl-1,5-octadien-3,7-diol (diendiol I) and pyran oxides of linalool did not show significant 
differences between the two ripening dates studied. In Airén grape variety normally the concentrations of the trans-isomer of pyran linalool oxide and diendiol I decreased continuously over the ripening period studied (Garcia et al., 2003). However results found in the Muscat Hamburg cultivar by Fenoll et al. (2009), showed that an increase of level of diendiol I was been related to an increase of linalool. Linalool has been proposed as the substrate for conversion to higher oxidation state compounds such as diendiol I (Wilson et al., 1984, 1986). In agreement with this proposal, in our study a significant correlation according Pearson's test $(p>0.05)$ was observed between linalool and diendiol I concentrations (data not shown). On the other hand, a decrease in the concentration of $\alpha$-terpineol, a terpene alcohol with floral character in berries (Ribéreau Gayon et al., 1975), was observed between the two ripening dates for all cultivars studied. Similar results were found in Muscat Hamburg during ripening by Fenoll et al. (2009).

$\mathrm{C}_{13}$-norisoprenoids have been identified as potential impact odorants in wines, particularly the compounds $\beta$-damascenone and $\beta$-ionone (Ferreira et al., 2000; Gomez-Miguez et al., 2007; Vilanova and Martinez, 2007). As is shown by Enzell (1985), carotenoid degradation can give rise to different highly flavorant $C_{13^{-}}$ norisoprenoid derivatives. Grapes and wines contain several $\mathrm{C}_{13^{-}}$ norisoprenoids such as $\beta$-damascenone, $\alpha$-ionone and others, so it would be expected that the carotenoid composition of grapes would have a noticeable effect on wine flavor (Razungles et al., 1988; Marais et al., 1992). $\beta$-Damascenone (fruity aroma) plays an important role in development of the characteristic Riesling aroma in wines (Chisholm et al., 1994). In our study, these compounds showed lower concentration in white cultivars than red cultivar Serradelo in the first date studied, and decreased at harvest date. In contrast it can be seen (Table 2 ) that $\mathrm{C}_{13}$-norisoprenoids show significant differences for all cultivars between the two ripening dates studied except for B. lexitimo. Studies realized with Fernão-Pires cultivar from Portugal showed that the total amount of monoterpenoids and $\mathrm{C}_{13}$-norisoprenoids increased from véraison to 20 days, where the maximum was reached, decreasing in the following weeks (Coello et al., 2007). In our study, $C_{13}$-norisopreniods $\beta$-damascenone and $\beta$-ionone were not present in Godello and $B$. lexitimo cultivars at the last ripening stage, however $\beta$-damascenone was one of the most powerful odorants for $B$. lexitimo and Agudelo white wines from Betanzos (Vilanova et al., 2009). Due to the fact that between verraison and maturity the glycosylation of $C_{13}$-norisoprenoids may occur, a decrease of these compounds in free form is expected (Razungles et al., 1988; Baumes et al., 2002). In Shiraz grape berries, increased concentrations of glycosylated precursors to $\beta$-damascenone have been associated with increased sunlight penetration to the fruiting zone of the vine (Bureau et al., 2000a,b; Ristic et al., 2010).

Total alcohols in the free fraction show an increase for all cultivars between the two dates studied with the exception of red Serradelo. White Godello and $B$. lexitimo cultivars showed higher values of total alcohols in the last ripening stage than those obtained for the other cultivars studied. A general conclusion from an earlier study reported that $\mathrm{C}_{6}$-compounds and alcohols reach their highest concentration during late ripening (Gomez et al., 1995; Kalua and Boss, 2009). The dominance of alcohols during late berry development, preceded by aldehydes, permits the use of the alcohols to aldehydes ratios in the prediction of harvest date for enhanced grape and wine aroma (Kalua and Boss, 2009). Among alcohols, 2-pentanol and 1-penten-3-ol were the only compounds stable during ripening (Table 3). E-2-Penten-1-ol and 1-penten-3-ol dominated the alcohol group in the two ripening stages for all cultivars with exception of the Agudelo cultivar. In general, benzyl alcohol and 2-phenylethanol presented the concentrations for all cultivars in the last ripening stage. Similarly, these compounds were detected in low concentrations in Muscat Hamburg cultivar and fluc- tuated during ripening (Fenoll et al., 2009). The levels of benzyl alcohol and 2-phenylethanol are quite high in non-Muscat grape cultivars in which terpenols are less abundant (Selli et al., 2003; Voirin et al., 1992; Dieguez et al., 2003; Rocha et al., 2000). At the last sampling time, it was possible to detect very low concentrations of 2-phenylethanol, which has a pleasant "rose" aroma, whereas the other alcohols are more herbaceous/purgent. The Literature indicates that 2-phenylethanol is very abundant in wines; however, it arises mainly from fermentation, with 2-phenylalanine being its precursor (Laminkanra et al., 1996). 2-Phenylethanol has a dual sensory effect, positive sensory attributes at low concentration and negative sensory attributes at elevated levels (Schwab et al., 2008).

Other compounds detected and quantified in the free fraction of the cultivars studied were volatile fatty acids, volatile phenols and carbonyl compounds (Tables 2 and 3). These three groups of volatile compounds showed significant differences among cultivars at the two ripening dates studied. Total free volatile fatty acids present a significant increase between the two dates in Agudelo and Serradelo cultivars, dominated by hexanoic acid. Hexanoic acid characterized to all cultivars showed an increase at the last ripening stage, with the highest concentration for red Serradelo cultivar. A decreased content of volatile fatty acids between ripening dates was shown for Godello white cultivar, in which hexanoic acid was detected only at last ripening stage. The interaction cultivar $*$ ripening date was significant for all compounds except for hexanoic acid and hexadecanoic acid. Previous studies shown that among volatile fatty acids, the concentration of octanoic acid was the highest for B. lexitimo, Agudelo and Serradelo wines (Vilanova et al., 2009). In this study also Agudelo presented the highest value of octanoic acid at last ripening stage.

No significant changes were detected in concentrations of total free volatile phenols and carbonyl compounds among the dates studied for Godello and Serradelo cultivars. Volatile phenols presented a decrease of total concentration for B. lexitimo and Serradelo during ripening while Agudelo increased its concentration in the last ripening stage. The evolution of these compounds has a tendency to a slight decrease during the ripening period in Macabeo, Airén and Chardonnay musts (Garcia et al., 2003). These authors suggested that this could be attributed to the dilution effect produced by water accumulation in the grape during this period. 4vinylguaiacol and vanillin concentrations showed low values and in most cases decreased during ripening of berries. Vanillin was the most abundant compound for all cultivars at last ripening stage with exception for Godello. Finally the level of carbonyl compounds also showed an increase during ripening for all cultivars except for Serradelo cultivar.

Results of ANOVA (Table 3) showed that the effect of "cultivar", "ripening date" and interaction "cultivar $*$ ripening date" on volatiles is important because $97.2 \%, 83.3 \%$ and $88.8 \%$, respectively of the volatiles quantified showed significant differences among cultivars.

\subsubsection{Glycosidically bound compounds}

Tables 4 and 5 show the evolution of groups of bound volatile compounds during ripening stages studied (mean and standard deviation), together with the ANOVA results for the factors "culti$\operatorname{var}(C)$ " and "ripening date (D)" and interaction C $*$ D. This study included 45 bound volatile compounds: 8 alcohols, $6 \mathrm{C}_{6}$-compounds, 6 volatile fatty acids, 12 monoterpenes, $5 \mathrm{C}_{13}$-norisoprenoids, 7 volatile phenols and 1 carbonyl compound. Differences among cultivars, ripening date and the effect of the ripening date on glycosidically bound volatiles were also analyzed.

ANOVA shows statistically significant differences among cultivars for all groups of volatile compounds studied with the exception of volatile phenols (Table 4). Differences between the two 
Table 4

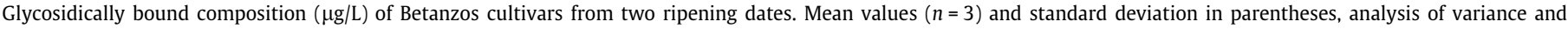
contrasts significance.

\begin{tabular}{|c|c|c|c|c|c|c|c|c|}
\hline Cultivar & Alcohols & $\mathrm{C}_{6}$-compounds & Monoterpenes & $\mathrm{C}_{13}$-norisoprenoids & $\begin{array}{l}\text { Volatile fatty } \\
\text { acids }\end{array}$ & $\begin{array}{l}\text { Volatile } \\
\text { phenols }\end{array}$ & $\begin{array}{l}\text { Carbonyl } \\
\text { compounds }\end{array}$ & Total \\
\hline \multicolumn{9}{|l|}{ Mean (SD) of bound volatile compounds } \\
\hline \multicolumn{9}{|l|}{ Ripening date 23.08.2007 (A) } \\
\hline Agudelo & $40.7(2.1) \mathrm{a}$ & $7.0(0.6) \mathrm{b}$ & $2.5(0.1) \mathrm{a}$ & $3.4(0.1) \mathrm{a}$ & $5.8(0.4) \mathrm{a}$ & $5.5(0.4) \mathrm{a}$ & $0.2(0.0) \mathrm{b}$ & $65.1(2.6) \mathrm{b}$ \\
\hline Godello & $11.5(4.4) \mathrm{b}$ & $1.7(0.5) \mathrm{a}$ & $2.5(0.8) \mathrm{a}$ & $5.3(2.0) \mathrm{b}$ & $1.3(0.1) \mathrm{a}$ & $5.0(3.3) \mathrm{a}$ & $1.0(0.1) \mathrm{c}$ & $28.4(11.3)$ a \\
\hline Blanco lexitimo & $20.0(2.5) c$ & $5.2(0.6) b$ & $12.1(3.1) \mathrm{b}$ & $2.3(0.1)$ a & $1.6(0.1) b$ & $9.9(1.6) b$ & nd a & $51.2(7.8) b$ \\
\hline Serradelo & $47.7(2.7) \mathrm{d}$ & $13.7(1.8) \mathrm{c}$ & $9.7(0.8) b$ & $3.5(0.1) a b$ & $7.3(1.3) \mathrm{c}$ & $12.5(1.0) \mathrm{b}$ & $0.2(0.0) \mathrm{b}$ & $94.6(5.0) \mathrm{c}$ \\
\hline \multicolumn{9}{|l|}{ Ripening date 30.08.2007 (B) } \\
\hline Agudelo & $56.5(0.9) \mathrm{a}$ & $9.1(0.1) b$ & $39.6(0.4) \mathrm{a}$ & $5.0(1.4) \mathrm{b}$ & $6.7(0.6) \mathrm{a}$ & $11.5(0.4) b$ & nd a & $128.4(1.7) \mathrm{c}$ \\
\hline Godello & $77.7(10.3) \mathrm{b}$ & $8.6(1.4) b$ & $9.1(1.0) \mathrm{b}$ & $8.6(0.5) c$ & $2.3(0.0) \mathrm{b}$ & $14.4(0.6) \mathrm{c}$ & $3.2(0.2) \mathrm{c}$ & $123.9(11.7) \mathrm{c}$ \\
\hline Blanco lexitimo & $14.8(1.6) \mathrm{c}$ & $5.2(1.3) \mathrm{a}$ & $13.2(2.8) \mathrm{c}$ & $1.6(0.3) \mathrm{a}$ & $4.9(0.0) \mathrm{c}$ & $9.7(1.6) \mathrm{ab}$ & $0.1(0.0) \mathrm{ab}$ & $49.6(7.6) \mathrm{a}$ \\
\hline Serradelo & $36.2(2.9) \mathrm{d}$ & $10.4(1.5) \mathrm{b}$ & $5.3(0.8) d$ & $1.1(0.1) \mathrm{a}$ & $7.9(1.1) \mathrm{d}$ & $6.7(0.8) b$ & $0.2(0.0) \mathrm{b}$ & $68.0(5.1) \mathrm{b}$ \\
\hline \multicolumn{9}{|l|}{ Analysis of variance p-values } \\
\hline Cultivar & $<0.0001$ & $<0.0001$ & $<0.0001$ & $<0.0001$ & $<0.0001$ & 0.419 & $<0.0001$ & $<0.0001$ \\
\hline Repetition & 0.228 & 0.344 & 0.034 & 0.959 & 0.732 & 0.244 & 0.211 & 0.071 \\
\hline Harvest date & $<0.0001$ & 0.007 & $<0.0001$ & 0.242 & 0.000 & 0.002 & $<0.0001$ & $<0.0001$ \\
\hline Cultivar $*$ ripening date & $<0.0001$ & $<0.0001$ & $<0.0001$ & 0.001 & 0.014 & $<0.0001$ & $<0.0001$ & $<0.0001$ \\
\hline \multicolumn{9}{|c|}{ Contrast $p$-values cultivar vs. ripening date } \\
\hline Agudelo-A vs. Agudelo-B & 0.000 & 0.035 & $<0.0001$ & 0.052 & 0.152 & 0.000 & 0.007 & $<0.0001$ \\
\hline Godello-A vs. Godello-B & 0.0001 & 0.0001 & 0.0001 & 0.001 & 0110 & $<0.0001$ & $<0.0001$ & $<0.0001$ \\
\hline Blanco lexitimo-A vs. Blanco lexitimo-B & 0.153 & 0.996 & 0.328 & 0.400 & $<0.0001$ & 0.878 & 0.086 & 0.768 \\
\hline Serradelo-A vs. Serradelo-B & 0.005 & 0.003 & 0.001 & 0.007 & 0.272 & 0.000 & 0.742 & 0.000 \\
\hline
\end{tabular}

nd: not detected. Duncan test: different letters indicates significant differences among cultivars. All the compounds were quantified as 4-nonanol equivalents.

ripening dates were significant for all groups of bound volatile compounds with exception for bound $\mathrm{C}_{13}$-norisoprenoids. The interaction cultivar $*$ ripening date was significant for all bound volatile groups. Significant changes of total bound concentration were found for all cultivars ( $p<0.0001$ ) except for B. lexitimo. Agudelo and Godello cultivars show a significant increase between the two ripening dates studied, showing the highest concentration of total volatile composition at the last date $(0.13$ and $0.12 \mathrm{mg} / \mathrm{L}$, respectively).

The bound alcohols showed the highest concentration for all cultivars at both dates studied, accounting for between $30 \%$ for $B$. lexitimo and $62 \%$ for Godello of the total bound fraction. Significant differences for alcohols were found among cultivars for the two ripening dates with exception of $B$. lexitimo. Godello cultivar showed the highest concentration of bound alcohols at the last date. Benzyl alcohol and 2-phenylethanol, with floral aromas, were the most abundant glycosidically bound compounds for all cultivars at the two ripening stages (Table 5). Both compounds were the two main aromatic compounds present in Muscat Hamburg grapes (Fenoll et al., 2009). Voirin et al. (1992) indicate that the presence of aromatic alcohols is associated with neutral cultivars.

$\mathrm{C}_{6}$-compounds and monoterpenes showed similar behavior, increasing their concentration for Agudelo and Godello cultivars and decreasing for Serradelo. This result shows clearly the interaction cultivar $*$ ripening date for these groups of compounds. Bound $\mathrm{C}_{6}$-compounds showed the highest value for Serradelo at first ripening and then, at the last ripening date this concentration was similar to those of Agudelo and Godello. (E)-2-Hexenal and 1-hexanol account for the highest concentrations, at the last date, for Agudelo and Godello cultivars, respectively. (Z)-2-Hexen-1-ol was not detected at harvest for any cultivar.

The concentration of monoterpenes was higher in bound form than free form, for all cultivars except for $B$. lexitimo. The highest level of total bound monoterpenes was detected for white Agudelo cultivar at the last ripening date. Red cultivar Serradelo had much more discrete levels of monoterpenic compounds than the other cultivars and this concentration was minor at the last ripening date. Similar results were observed in Vinhão red cultivar from Portugal, where only traces of monoterpenes were found (Oliveira et al., 2004). Bound 3,7-dimethyl-1,5-octadien-3,7-diol (diendiol I) was the most abundant compound for Agudelo, B. lexitimo and Serradelo in the first date and decreased in the last date, except for Agudelo cultivar. A significant positive correlation according to Pearson's test $(p>0.05)$ was observed between bound linalool and diendiol I concentrations (data not shown). Nerol, (E)-8-hydroxy-linalool, (Z)-8-hydroxy-linalool and HO-trienol were only detected in the bound form for the Betanzos cultivars. Levels of geraniol in the bound fraction were much higher than those found in the free fraction and this compound showed an increase between the two dates studied for Godello and Agudelo cultivars. Similar results were found by Fenoll et al. (2009) for Muscat Hamburg during ripening.

Among the cultivars studied, Godello showed the highest concentration of bound $\mathrm{C}_{13}$-norisoprenoids at the last date followed by Agudelo cultivar. With regard to bound $\mathrm{C}_{13}$-norisoprenoids, the concentrations of 3-hydroxy- $\beta$-damascone and 3-oxo-7,8-dehydro- $\alpha$-ionol did not show changes between the two ripening dates studied. 3-Oxo- $\alpha$-ionol presented the highest concentration for Agudelo cultivar in the last date, followed by 3 -oxo- $\alpha$-ionol for Godello. Qualitatively, the $\mathrm{C}_{13}$-norisoprenoid compositions of the berries for the most varieties are quite similar at the last date. The major aglycons are 3-hydroxy- $\beta$-damascone, 3-oxo- $\alpha$-ionol, and 3-oxo-7,8-dehydro- $\alpha$-ionol in accordance with data reported for other cultivars (Razungles et al., 1988).

Other compounds detected and quantified in the bound fraction were volatile fatty acids, volatile phenols and 1 carbonyl compound. The level of volatile fatty acids showed an increase between the two ripening stages only for all white B. lexitimo cultivar. Serradelo red cultivar presented major level of bound volatile acids in the two dates studied. Hexanoic acid was the most abundant compound for Agudelo and Godello cultivars at ripe stage, however hexadecanioc acid showed major values for $B$. lexitimo and Serradelo.

Volatile phenols in bound form increased their concentration for Agudelo and Godello during ripening showing significant 
Table 5

Changes in glicosidically bound composition of Betanzos grape cultivars during ripening.

\begin{tabular}{|c|c|c|c|c|c|c|c|c|c|c|c|}
\hline \multirow[t]{3}{*}{ Bound compounds $(\mu \mathrm{g} / \mathrm{L})$} & \multicolumn{8}{|c|}{ Ripening date } & \multirow{2}{*}{\multicolumn{3}{|c|}{ ANOVA }} \\
\hline & \multicolumn{4}{|c|}{ 23.08.2007 (A) } & \multicolumn{4}{|c|}{ 30.08.2007 (B) } & & & \\
\hline & Agudelo & Godello & B. lexitimo & Serradelo & Agudelo & Godello & B. lexitimo & Serradelo & $\mathrm{C}$ & $\mathrm{D}$ & $\mathrm{C} * \mathrm{D}$ \\
\hline \multicolumn{12}{|l|}{ Monoterpenes } \\
\hline trans-Furan linalool oxide & 0.17 & 0.33 & 0.80 & 0.63 & 3.26 & 0.93 & 1.13 & 0.42 & $* * *$ & $* * *$ & ${ }^{* * *}$ \\
\hline cis-Furan linalool oxide & nd & nd & 0.70 & 1.33 & 2.80 & 2.60 & 0.78 & 0.67 & $* * *$ & $* * *$ & $* * *$ \\
\hline 3,7-Dimethylocta-1,5-dien-3,7-diol & 1.60 & nd & 3.59 & 2.53 & 8.31 & nd & 3.36 & 1.45 & $* * *$ & $* * *$ & $* * *$ \\
\hline trans-Pyran linalool oxide & nd & 0.20 & 0.25 & 0.31 & 0.76 & 0.39 & 0.22 & 0.24 & ${ }^{* *}$ & *** & $* * *$ \\
\hline cis-Pyran linalool oxide & 0.12 & nd & 0.14 & 0.21 & nd & nd & 0.14 & 0.19 & $* * *$ & $* *$ & $* *$ \\
\hline (E)-8-Hydroxy-linalool & nd & 0.81 & 0.38 & 1.02 & 1.42 & 1.45 & 0.34 & 0.37 & $* * *$ & $* * *$ & $* * *$ \\
\hline (Z)-8-Hydroxy-linalool & nd & 0.29 & 1.09 & 0.84 & 6.42 & 0.75 & 1.13 & 0.59 & $* * *$ & $* * *$ & $* * *$ \\
\hline HO-trienol & 0.29 & nd & 0.37 & 0.21 & 1.06 & nd & 0.42 & 0.11 & $* * *$ & $* * *$ & $* * *$ \\
\hline Geraniol & 0.33 & 0.71 & 2.26 & 1.13 & 3.24 & 2.15 & 2.00 & 0.62 & $* * *$ & $* * *$ & $* * *$ \\
\hline Nerol & nd & 0.13 & 0.76 & 0.21 & 0.60 & 0.36 & 0.66 & 0.21 & $* * *$ & *** & $* * *$ \\
\hline Linalool & nd & nd & 0.59 & 0.48 & 9.77 & 0.45 & 1.98 & 0.29 & $* * *$ & $* * *$ & $* * *$ \\
\hline$\alpha$-Terpineol & nd & nd & 1.21 & 0.76 & 1.96 & nd & 1.10 & 0.18 & $* * *$ & *** & $* * *$ \\
\hline \multicolumn{12}{|l|}{$C_{13}$-norisoprenoids } \\
\hline 3-Hydroxy- $\beta$-damascone & 1.56 & 1.01 & 0.77 & nd & nd & 2.50 & nd & 0.67 & $* * *$ & ns & $* * *$ \\
\hline 3-Hydroxy-7,8-dehydro- $\beta$-ionol & nd & 1.32 & nd & 1.63 & nd & 3.84 & nd & nd & $* * *$ & $*$ & $* * *$ \\
\hline 3-Oxo-7,8-dihydro- $\alpha$-ionol & nd & 0.93 & nd & nd & nd & nd & nd & nd & $*$ & ns & * \\
\hline 3-Oxo- $\alpha$-ionol & 0.99 & 1.01 & 1.50 & 0.95 & 5.00 & 1.15 & 1.61 & nd & $* * *$ & $* * *$ & $* * *$ \\
\hline $4-O x o-\beta$-ionol & 0.83 & 1.08 & nd & 0.95 & nd & 1.15 & nd & 0.47 & $* * *$ & $* * *$ & $* * *$ \\
\hline \multicolumn{12}{|l|}{$C_{6}$-compounds } \\
\hline (E)-2-Hexenal & 3.85 & 1.10 & 2.65 & 6.56 & 1.54 & 4.77 & 1.35 & 1.62 & $* * *$ & $* * *$ & $* * *$ \\
\hline 1-Hexanol & 1.46 & 0.58 & 1.38 & 4.04 & 6.43 & 2.20 & 1.81 & 3.49 & $* * *$ & $* * *$ & $* * *$ \\
\hline (E)-3-Hexen-1-ol & nd & nd & nd & 3.08 & nd & nd & nd & 1.47 & $* *$ & $* * *$ & ** \\
\hline (Z)-3-Hexen-1-ol & 0.77 & nd & 0.88 & nd & 1.14 & 0.76 & 1.43 & 1.88 & $* * *$ & $* * *$ & $* * *$ \\
\hline (E)-2-Hexen-1-ol & nd & nd & 0.31 & nd & nd & 0.83 & 0.60 & 1.94 & $* * *$ & $* * *$ & $* * *$ \\
\hline (Z)-2-Hexen-1-ol & 0.90 & nd & nd & nd & nd & nd & nd & nd & $* * *$ & $* * *$ & ${ }^{* * *}$ \\
\hline \multicolumn{12}{|l|}{ Alcohols } \\
\hline 2-Pentanol & 0.85 & nd & 1.87 & 1.85 & nd & 1.41 & 1.53 & 1.91 & $* * *$ & ns & $* *$ \\
\hline 1-Butanol & 1.55 & nd & nd & nd & nd & nd & nd & nd & $* * *$ & $* * *$ & $* * *$ \\
\hline 3-Methyl-1-butanol & 0.98 & 0.41 & 0.28 & 1.38 & 12.51 & 1.91 & 0.82 & 3.59 & $* * *$ & $* * *$ & $* * *$ \\
\hline 3-Methyl-2 butanol & 0.59 & nd & 0.36 & 0.40 & nd & 1.25 & 0.17 & 0.27 & $* * *$ & ns & $* * *$ \\
\hline 1-Octanol & 0.09 & nd & nd & 0.20 & 0.52 & nd & 0.13 & nd & $* * *$ & $* * *$ & $* * *$ \\
\hline Benzyl alcohol & 33.16 & nd & 12.96 & 31.78 & 22.56 & 43.17 & 8.62 & 24.20 & $* * *$ & $* * *$ & $* * *$ \\
\hline 2-Phenylethanol & 3.42 & 10.92 & 4.58 & 11.56 & 20.94 & 29.41 & 3.53 & 6.25 & $* * *$ & ${ }^{* * * *}$ & $* * *$ \\
\hline 2-Phenoxyethanol & nd & 0.21 & nd & 0.54 & nd & 0.56 & nd & nd & $* * *$ & $* * *$ & $* * *$ \\
\hline \multicolumn{12}{|l|}{ Volatile fatty acids } \\
\hline Hexanoic acid & 1.36 & 0.29 & nd & nd & 3.52 & 0.81 & 0.45 & nd & $* * *$ & $* * *$ & $* * *$ \\
\hline (E)-2-Hexenoic acid & 1.29 & nd & nd & nd & 2.53 & nd & nd & nd & $* * *$ & $* *$ & $* * *$ \\
\hline Octanoic acid & 0.94 & 0.27 & 0.63 & 0.53 & 0.62 & nd & 0.38 & 0.36 & $* * *$ & $* * *$ & ns \\
\hline Nonanoic acid & 0.95 & 0.09 & 0.16 & 0.27 & nd & nd & 0.24 & 0.37 & $* * *$ & $* * *$ & $* * *$ \\
\hline Decanoic acid & 0.66 & nd & 0.42 & nd & nd & nd & 0.31 & nd & $* * *$ & $* * *$ & $* * *$ \\
\hline Hexadecanoic acid & nd & nd & nd & 5.71 & nd & nd & 2.89 & 7.03 & $* * *$ & $* * *$ & ${ }^{* * *}$ \\
\hline \multicolumn{12}{|l|}{ Volatile phenols } \\
\hline Methyl salicilate & 0.28 & 0.70 & 0.54 & 2.37 & 0.63 & 1.52 & 1.02 & 1.57 & $* * *$ & * & $* * *$ \\
\hline Eugenol & 0.75 & 0.46 & 3.10 & 0.58 & 1.85 & 1.07 & 2.94 & 0.26 & $* * *$ & $* * *$ & ${ }^{* * *}$ \\
\hline 4-Vinylguaiacol & 0.88 & 3.08 & 2.01 & 2.64 & 3.25 & 11.83 & 2.58 & 2.08 & $* * *$ & $* * *$ & $* * *$ \\
\hline 4-Vinylphenol & 0.46 & nd & 0.43 & nd & nd & nd & nd & nd & $* * *$ & $* * *$ & $* * *$ \\
\hline Vanillin & 0.89 & 0.28 & 1.21 & 3.70 & nd & nd & 0.91 & 1.42 & $* * *$ & $* * *$ & $* * *$ \\
\hline Methyl vanilate & 1.55 & 0.27 & 1.54 & 2.24 & 4.27 & nd & 1.50 & 0.96 & $* * *$ & $* * *$ & $* * *$ \\
\hline Acetovanillone & 0.73 & 0.23 & 1.09 & 0.95 & 1.51 & nd & 0.80 & 0.47 & $* * *$ & ns & $* * *$ \\
\hline \multicolumn{12}{|l|}{ Carbonyl compounds } \\
\hline Benzaldehyde & 0.22 & 0.99 & nd & 0,22 & nd & 3.22 & 0.13 & 0.25 & $* * *$ & $* * *$ & $* * *$ \\
\hline
\end{tabular}

C: cultivar; D: harvest date; ns: not significance; nd: not detected. All the compounds were quantified as 4-nonanol equivalents.

* Significance at $95 \%$ level.

** Significance at $99 \%$ level.

*** Significance at $99.9 \%$ level.

differences among cultivars at both dates. Eugenol, 4-vinylphenol and acetovanillone only were detected in the bound fraction. These compounds showed the highest values for most cultivars with fluctuations between the two ripening stages. Eugenol glycosides were detected at low concentration in Muscat Hamburg grapes (Fenoll et al., 2009). Acetovainillone was the only stable phenol volatile between both data analyses.

Finally, the carbonyl compounds group showed the lowest concentration for all cultivars at the two ripening dates. Benzaldehyde was found in both fractions in ripe cultivars, except for Agudelo in the bound fraction.

Results of the ANOVA (Table 5) showed that the effect of "cultivar" on volatiles is important because $100 \%$ of the volatiles quantified showed significant differences among cultivars. Data in Table 5 also presents ANOVA results for the factor ripening date, where the concentration of five compounds did not vary significantly among dates (two $\mathrm{C}_{13}$-norisoprenoids, two alcohols and one phenol volatile). Finally, a total of 44 volatile compounds (97.7\% of total 
volatiles quantified) present a significant interaction between the two factors, cultivar and ripening date.

\section{Concluding remarks}

During ripening, substantial changes take place in the composition of grapes. Therefore, it is important to choose the correct moment for their harvest because grape composition will determine the quality of the resulting wine. In this work the volatile composition of cultivars from Betanzos (NW Spain) was strongly influenced by the cultivar and the ripening stage. The results also showed significant interaction "cultivar $*$ ripening date" for $93.8 \%$ of volatile compounds quantified. The increase of free total volatile concentration was only significant for Godello and Serradelo cultivars between the two ripening dates studied, because of the high levels of $\mathrm{C}_{6}$-compounds, $(E)$-2-hexenal, $(E)$-2-hexen1-ol and 1-hexanol. Godello cultivar showed the maximum value of volatile composition coincident with the last ripening data studied (August 30 ). White B. lexitimo was characterized by a higher concentration of monoterpenes (linalool) at last ripening date. It will permit to produce more terpene-rich wines when the harvest is delayed. Agudelo cultivar showed a high level of bound monoterpenes on the first harvest date. The red cultivar Serradelo also showed a high level of bound compounds at first harvest date analyzed, however technologic maturation is incomplete at this time. The results of this study showed that the evolution of the volatile composition during ripening was not proportional to the changes in the sugar content and ratio sugar/acid content of grapes, which shows that the technological and aroma ripening did not occur at the same time. For this reason, it is of great importance to know the evolution of volatiles during ripening and the corresponding sugar/acidity ratio. This type of information about the raw material of wine represents a helpful tool to support decisions of the winemaker based on the wine type.

\section{Experimental}

\subsection{Sampling and processing}

Grapes from V. vinifera B. lexitimo, Agudelo, Godello and Serradelo cultivars were collected in Betanzos Geographical Denomination (NW Spain) from Lorenzo Bescansa vineyard (latitude $43^{\circ} 17^{\prime} \mathrm{N}$ and longitude $0^{\circ} 13^{\prime} \mathrm{W}$ ). The samples were collected in triplicate, at two ripening dates. For each sample, 300 grape berries were picked randomly throughout the vine, taking into consideration the number of berries per bunch, and the balance between shadow and sun exposure in the vineyard. Samples were transported immediately to the laboratory. Grape berry samples were manually crushed for analysis of the ${ }^{\circ}$ Brix and titratable acidity (TA). The other samples were stored and frozen at $-20^{\circ} \mathrm{C}$ until volatile compounds analysis. ${ }^{\circ}$ Brix was determined using a hand-held refractometer while TA, being expressed as percentage of tartaric acid, was determined using $100 \mathrm{mmol} / \mathrm{L} \mathrm{NaOH}$ (OIV Official Methods). The characteristics of grape cultivars from Betanzos for the two ripening data are shown in Table 1.

\subsection{Solvents}

All the solvents used were of at least gas chromatographic grade: ethyl acetate (Merck, SupraSolv), dichloromethane (Merck, SupraSolv), methanol (Merck, SupraSolv) and pentane (Merck, UniSolv). Azeotrope pentane-dichloromethane $(2: 1 \mathrm{v} / \mathrm{v})$ was distilled after combination of pentane and dichloromethane and redistilled whenever necessary.

\subsection{Extraction of free and bound fractions}

About $550 \mathrm{~g}$ of frozen berries were thawed at $4{ }^{\circ} \mathrm{C}$ overnight, and then manually crushed, centrifuged $(R C F=9660,20 \mathrm{~min}$, $4{ }^{\circ} \mathrm{C}$ ) and filtered through a glass wool bed. To $200 \mathrm{~mL}$ of juice, $2.35 \mu \mathrm{g}$ of 4-nonanol (Merck, Ref. 818773) were added and passed through a LiChrolut EN cartridge (Merck, $500 \mathrm{mg}, 40-$ $120 \mu \mathrm{m}$ ) according to Ibarz et al. (2006) and Oliveira et al. (2008). The resin was previously pre-conditioned with $5 \mathrm{~mL}$ of methanol and $10 \mathrm{~mL}$ of aqueous alcoholic solution $(10 \%, \mathrm{v} / \mathrm{v})$. Free and bound fractions were eluted successively with $5 \mathrm{~mL}$ of pentane-dichloromethane azeotrope and $7 \mathrm{~mL}$ of ethyl acetate. The pentane-dichloromethane elute was dried over anhydrous sodium sulfate and concentrated to $200 \mu \mathrm{L}$ by solvent evaporation at $34^{\circ} \mathrm{C}$ through a Vigreux and then a Dufton column, prior to analysis. The ethyl acetate eluate was concentrated to dryness in vacuum $\left(40^{\circ} \mathrm{C}\right)$ and re-dissolved in $200 \mu \mathrm{L}$ of $100 \mathrm{mmol} / \mathrm{L}$ citrate-phosphate buffer $(\mathrm{pH}=5.0)$. Residual free compounds were extracted five times with azeotropic mixture and discarded. Fourteen milligrams of enzyme AR2000 (Gist-Brocades) were added to the glycoside extract and the mixture was incubated at $40{ }^{\circ} \mathrm{C}$, for $12 \mathrm{~h}$. Released aglycons were extracted with pentane-dichloromethane azeotrope, after addition of $2.35 \mu \mathrm{g}$ of 4 -nonanol as internal standard. The organic phase was then concentrated to $200 \mu \mathrm{L}$ through a Dufton column. The extractions were made in triplicate.

\subsection{Chromatographic analysis}

Gas chromatographic analysis of volatile compounds was performed using a GC-MS system constituted by a Varian 3400 chromatograph and an ion-trap mass spectrometer Varian Saturn II. A $1 \mu \mathrm{L}$ injection was made into a capillary column, coated with CP-Wax 52 CB ( $50 \mathrm{~m} \times 0.25 \mathrm{~mm}$ i.d., $0.2 \mu \mathrm{m}$ film thickness, Chrompack). The temperature of the injector (SPI-septum-equipped programmable temperature) was programmed from 20 to $250^{\circ} \mathrm{C}$, at $180^{\circ} \mathrm{C} / \mathrm{min}$. The oven temperature was held at $40^{\circ} \mathrm{C}$, for $5 \mathrm{~min}$, then programmed to rise from 40 to $250{ }^{\circ} \mathrm{C}$, at $3^{\circ} \mathrm{C} / \mathrm{min}$, then held $20 \mathrm{~min}$ at $250^{\circ} \mathrm{C}$ and finally programmed to go from 250 to $255^{\circ} \mathrm{C}$ at $1{ }^{\circ} \mathrm{C} / \mathrm{min}$. The carrier gas was helium N60 (Air Liquide) at $103 \mathrm{kPa}$, which corresponds to a linear speed of $180 \mathrm{~cm} / \mathrm{s}$ at $150^{\circ} \mathrm{C}$. The detector was set to electronic impact mode $(70 \mathrm{eV})$, with an acquisition range from 29 to $360 \mathrm{~m} / z$, and an acquisition rate of $610 \mathrm{~ms}$.

\subsection{Identification and quantification of volatile compounds}

Identification was performed using the software Saturn version 5.2 (Varian), by comparing mass spectra and retention indices with those of pure standard compounds. All of the compounds were quantified as 4-nonanol equivalents.

\subsection{Statistical analyses}

The data were analyzed using XLstat-Pro (Addinsoft 2009). A mixed model ANOVA was performed on the volatile compounds analysis data. Cultivar, repetition and ripening date, as well as the two-way interaction treatment cultivar $*$ ripening date were evaluated for significance. The differences among cultivars and cultivar composition between two ripening stages were evaluated using a priori contrast $(p<0.05)$. The mean differences between cultivars were calculated using the least significant difference Fishers' test. 


\section{Acknowledgments}

The authors thank to Xunta de Galicia (Spain) and Adega Lorenzo Bescansa S.U.L. for financial support for this work (PGIDIT07TAL026E Research Project). Dr. Vilanova also thanks to Xunta de Galicia for the Isidro Parga Pondal program.

\section{References}

Allen, M.S., Lacey, M.J., Harris, R.L.N., Brown, W.V., 1991. Contribution of methoxypyrazines to Sauvignon blanc wine aroma. Am. J. Enol. Viticult. 42, 109-112.

Arevalo, M., Diez, J., Ubeda, J.F., Navascues, E., Briones, A.I., 2006. A rapid method for quantifying aroma precursors: application to grape extract, musts and wines made from several varieties. Food Chem. 99, 183-190.

Bayonove, C., Cordonnier, R., 1971. Reserches sur larôme du Muscat. Etude de la fraction terpenique. Ann. Technol. Agric. 20 (4), 347-355.

Bayonove, C.L., Baumes, R.L., Crouzet, J., Günata, Y.Z., 1998. Arômes. In: Flanzy, C. (Ed.), Oenologie - Fondements Scientifiques et Technologiques. Lavoisier Tec Doc, Paris, pp. 163-235.

Belancic, A., Agosin, E., 2007. Methoxypyrazines in grapes and wines of Vitis vinifera ev. Carmenere. Am. J. Enol. Viticult. 58 (4), 462-469.

Bueno, J.E., Peinado, R., Moreno, J., Medina, M., Moyano, L., Zea, L., 2003. Selection of volatile aroma compounds by statistical and enological criteria for analytical differentiation of musts and wines of two grape varieties. J. Food Sci. 68, 158163.

Bureau, S.M., Baumes, R.L., Razungles, A.J., 2000a. Effects of vine or bunch shading on the glycosylated flavor precursors of Vitis vinifera L. cv. Syrah. J. Agric. Food Chem. 48, 1290-1297.

Bureau, S.M., Razuncles, A.J., Baumes, R.L., 2000b. The aroma of Muscat de Frontignan grapes: effect of the ligh environment of vine or bunch on volatiles and glycoconjugates. J. Sci. Food Agric. 80, 2012-2020.

Cabaroglu, T., Canbasm, A., Baumesm, R.L., Bayonove, C.L., Lepoutrem, J.P., Gunatam, Y., 1997. Aroma composition of a white wine of Vitis vinifera L. cv. Emir as affected by skin contact. J. Food Sci. 62, 680-683.

Camara, J.S., Herbert, P., Narques, J.C., Alves, M.A., 2004. Varietal flavour compounds of tour grape varieties producing Madeira wines. Anal. Chem. Acta 513, $203-$ 207.

Chisholm, M.G., Guiher, L.A., Vonah, T.M., Beaumont, J.L., 1994. Comparison of some French-American hybrid wines with White Riesling using gas chromatographyolfactometry. Am. J. Enol. Viticult. 45, 201-212.

Coello, E., Rocha, S.M., Barros, A.S., Delgadillo, I., Coimbra, M.A., 2007. Screening of variety- and pre-fermentation-related volatile compounds during ripening of white grapes to define their evolution profile. Anal. Chem. Acta 597, 257-264.

Cordonnier, R., Bayonove, C., 1974. Mise en evidence dans la baie de raisin, vari6te Muscat d'Alexandrie, de monoterpenes lies revelables par une ou plusieurs enzymes du fruit. CR Acad. Sci. Paris, Ser. D. 278, 3387-3390.

Cox, A., Capone, D.L., Elsey, G.M., Perkins, M.V., Sefton, M.A., 2005. Quantitative analysis, occurrence, and stability of $(E)-1-(2,3,6$-trimethylphenyl)buta-1,3diene in wine. J. Agric. Food Chem. 53, 3584-3591.

Dieguez, S.C., Lois, L.C., Gomez, E.F., de la Peña, M.L.G., 2003. Aromatic composition of the Vitis vinifera grape Albariño. LWT-Food Sci. Technol. 36, 585-590.

Enzell, C., 1985. Biodegradation of carotenoids-an important route to aroma compounds. Pure Appl. Chem. 57 (5), 693-700.

Fenoll, J., Manso, A., Hellín, P., Ruiz, L., Flores, P., 2009. Changes in the aromatic composition of the Vitis vinifera grape Muscat Hamburg during ripening. Food Chem. 114, 420-428.

Ferreira, D., Lopes, R., Cacho, J., 2000. Quantitative determination of the odorants of young red wines from different grape varieties. J. Agric. Food Chem. 80, 16591667.

Garcia, E., Chacón, J.L., Martinez, J., Izquierdo, P.M., 2003. Changes in volatile compounds during ripening in grapes of Airen, Macabeo and Chardonnay white varieties grown in la Mancha Region (Spain). Food Sci. Techol. Int. 9 (1), 33-41.

Genisheva, Z., Oliveira, J.M., 2009. Monoterpenic characterization of white cultivars from Vinhos verdes Appellation of Origin (North Portugal). Int. J. Inst. Brew. 115, 308-315.

Gomez, E., Martínez, A., Laencina, J., 1995. Changes in volatile compounds during maturation of some grape varieties. J. Agric. Food Chem. 67, 229-233.

Gomez-Miguez, M.J., Cacho, J., Ferreira, D., Vicario, I.M., Heredia, A., 2007. Volatile components of Zalema white wines. Food Chem. 100, 1464-1473.

Günata, Y.Z., Bayonove, C.L., Baumes, R.L., Cordonnier, R.E., 1985. The aroma of grapes. I. Extraction and determination of free and glycosidically bound fractions of some grape aroma components. J. Chromatogr. A 331, 83-90.

Hardy, P.J., 1970. Changes in volatiles of Muscat grapes during ripening. Phytochemistry 9, 709-715.

Hashizume, K., Samuta, T., 1999. Grape maturity and light exposure affect berry methoxypyrazine concentration quality. Am. J. Enol. Viticult. 50, 194-198.

Ibarz, M.J., Ferreira, V., Hernández-Orte, P., Loscos, N., Cacho, J., 2006. Optimization and evaluation of a procedure for the gas chromatographic-mass spectrometric analysis of the aromas generated by fast acid hydrolysis of flavor precursors extracted from grapes. J. Chromatogr. A 1116, 217-229.

Kalua, C.M., Boss, P.K., 2009. Evolution of volatile compounds during the development of Cabernet Sauvignon grapes (Vitis vinifera L.). J. Agric. Food Chem. 57, 3818-3830.
Kalua, C.M., Boss, P.K., 2010. Comparison of major volatile compounds from Riesling and Cabernet Sauvignon grapes (Vitis vinifera L.) from fruitset to harvest. Aust. J. Grape Wine Res. 16, 337-348.

Laminkanra, O., Grimm, C.C., Inyang, I.D., 1996. Formation and occurrence of flavor components in Noble muscadine wine. Food Chem. 56, 373-376.

Marais, J., 1983. Terpenes in the aroma of grapes and wines: a review. S. Afr. J. Enol. Viticult. 4 (2), 49-60.

Marais, J., van Wyk, C., 1986. Effect of grape maturity and juice treatments on terpene concentrations and wine quality of Vitis vinfera L. cv. Weisser Riesling and Bukettraube. S. Afr. J. Enol. Viticult. 7, 26-35.

Marais, J., van Wik, C., Rapp, A., 1992. Effect of sunlight and shade on norisoprenoid levels in maturing Weisser Rieling and Chenin blanc wines. S. Afr. J. Enol. Viticult. 13, 23-32.

Mateo, J.J., Jiménez, M., 2000. Monoterpenes in grape juice and wines. J Chromatogr. A 881, 557-567.

Moio, L., Ugliano, M., Gambuti, A., Genovese, A., Piombino, P., 2004. Influence of clarification treatment on concentrations of selected free varietal aroma compounds and glycoconjugates in Falang (Vitis vinifera L.) must and wine. Am. J. Enol. Viticult. 55, 7-12.

Muñoz-Organero, G., Ortiz, J.M., Cabellos, J.M., Arroyo, T., 1998. Algunos compuestos aromáticos en el mosto de moscatel y de otras variedades de vid. Viticult./Enol. Profesional 56, 48-55.

Nicolini, G., Versini, G., Amadei, E., Marchio, M., 1996. 3-hexen-1-ol isomers in Müller-Thurgau wines: a "varietal" characteristic affected by must sulfiting time. Vitis 35 (3), 117-148.

O.I.V., 1990. Recueil des méthodes internacionales danalyse des vins et des moûts. Office Internetional de la Vigne et du Vin, Paris.

Oliveira, J.M., Maia, M.O., Baumes, R.L., Bayonove, C.L., 2000. Free and bound aromatic components of Loureiro and Alvarinho grape varieties from the Vinhos Verdes region. Viticult. Enol. Sci. 55, 13-20.

Oliveira, J.M., Araújo, I., Pereira, O.M., Maia, J.S., Amaral, A.J., Maia, M.O., 2004 Characterization and differentiation of five "Vinhos Verdes" grape varieties on the basis of monoterpenic compounds. Anal. Chem. Acta 513, 269-275.

Oliveira, J.M., Faria, M., Sá, F., Barros, F., Araújo, I.M., 2006. $C_{6}$-alcohols as varietal markers for assessment of wine origin. Anal. Chem. Acta 563, 300-309.

Oliveira, J.M., Oliveira, P., Baumes, R.L., Maia, M.O., 2008. Volatile and glycosidically bound composition of Loureiro and Alvarinho wines. Food Sci. Technol. Int. 14 341-353.

Razungles, A., Bayonove, C.L., Cordonnier, R.E., Sapis, J.C., 1988. Grape carotenoids: changes during the maturation period and localisation in mature berries. Am. J. Enol. Viticult. 39 (1), 44-48.

Ribéreau Gayon, P., Boidron, J.N., Terrier, A., 1975. Aroma of Muscat grape varieties. J. Agric. Food Chem. 23, 1042-1047.

Ribéreau-Gayon, P., Glories, Y., Maujean, A., Dubourdieu, D., 2000. Varietal aroma. In: Handbook of Enology, vol. 2. The Chemistry of Wine and Stabilization and Treatments. John Wiley Sons Ltd., pp. 187-206.

Ristic, R., Bindon, K., Francis, L.I., Herderich, M.J., Iland, P.G., 2010. Flavonoids and $\mathrm{C}_{13}$-norisoprenoids in Vitis vinifera L. cv. Shiraz: relationships between grape and wine composition, wine colour and wine sensory properties. Aust. J. Grape Wine Res. 16 (3), 369-388.

Rocha, S.M., Coutinho, P., Barros, A., Coimbra, M.A., Delgadillo, I., Cardoso, A.D., 2000 Aroma potential of two Bairrada white grape varieties: Maria Gomes and Bical. J. Agric. Food Chem. 48, 4802-4807.

Rocha, S.M., Coutinho, P., Barros, A., Delgadillo, I., Coimbra, M.A., 2007. Establishment of the varietal volatile profile of musts from white Vitis vinifera L. varieties. J. Sci. Food Agric. 87, 1667-1676.

Salinas, M.R., Zalacain, A., Pardo, F., Alonso, G.L., 2004. Stir bar sorptive extraction applied to volatile constituents evolution during Vitis vinifera ripening. J. Agric Food Chem. 52 (15), 4821-4827.

Sánchez Palomo, E., Diaz-Maroto, M.C., González Viñas, M.A., Soriano-Pérez, A., Perz-Coello, M.S., 2007. Aroma profile of wines from Albillo and Muscat grape varieties at different stages of ripening. Food Control 18, 398-403.

Schwab, W., Davidovich-Rikanati, R., Lewinsohn, E., 2008. Biosynthesis of plantderived flavor compounds. Plant J. 54, 712-732.

Sefton, M.A., Francis, I.L., Williams, P.J., 1993. The volatile composition of Chardonnay juices: a study by flavor precursor analysis. Am. J. Enol. Viticult. 44, 359-369.

Segurel, M.A., Razungles, A., Riou, C., Salles, M., Baumes, R.L., 2004. Contribution of dimethyl sulfide to the aroma of Syrah and Grenache noir wines and estimation of its potential in grapes of these varieties. J. Agric. Food Chem. 52, 7084-7093.

Segurel, M.A., Razungles, A., Riou, C., Trigueiro, M.G., Baumes, R.L., 2005. Ability of possible DMS precursors to release DMS during wine aging and in the conditions of heat-alkaline treatment. J. Agric. Food Chem. 53, 2637-2645.

Selli, S., Cabaroglu, T., Canbas, A., Erten, H., Nurgel, C., 2003. Effect of skin contact on the aroma composition of the musts of Vitis vinifera L. cv. Muscat of Burnova and Narince grown in Turkey. Food Chem. 81, 341-347.

Swiegers, J.H., Pretorius, I.S., 2005. Yeast modulation of wine flavour. Adv. Appl. Microbiol. 57, 131-175.

Tominaga, T., Guyot, R.B., Peyrot des Gachons, C., Dubourdieu, D., 2000 Contribution of volatile thiols to the aromas of white wines made from several Vitis vinifera grape varieties. Am. J. Enol. Viticult. 51, 178-181.

Versini, G., 1985. On the aroma of "Traminer aromatico" or "Gewürztraminer" wine. Vignevini 12, 57-65.

Versini, G., Orriols, I., Deleserra, A., 1994. Aroma components of Galician Albariño, Loureira and Godello wines. Vitis 33, 165-170. 
Vilanova, M., Martinez, C., 2007. First study of determination of aromatic compounds of red wine from Vitis vinifera cv. Castanal grown in Galicia (NW Spain). Eur. Food Res. Technol. 224, 431-436.

Vilanova, M., Zamuz, S., Vilariño, F., Sieiro, C., 2007. Effect of terroir on the volatiles of Vitis vinifera cv. Albariño. J. Sci. Food Agric. 87, 1252-1256.

Vilanova, M., Genisheva, Z., Bescansa, L., Masa, A., Oliveira, J.M., 2009. Volatile composition of wines from Vitis vinifera Agudelo, Serradelo and Blanco lexitimo from Betanzos (NW Spain). J. Inst. Brew. 115 (1), 35-40.

Voirin, S.G., Baumes, R., Sapis, C.L., Bayonove, C., 1992. Analytical methods for monoterpene glycosides in grape and wine II. Qualitative and quantitative determination of monoterpene glycosides in grape. J. Chromatogr. 592, 269281.

Williams, P.J., Sefton, M.A., Wilson, B., 1989. Nonvolatile conjugates of secondary metabolites as precursors of varietal grape flavour components. In: Teranishi,
R., Buttery, R.G., Shahidi, F. (Eds.), Flavor Chemistry, Trends and Developments, ACS Symposium Series No. 388. American Chemical Society, Washington, DC pp. $35-48$

Wilson, B., Straus, C.R., Williams, P.J., 1984. Changes in free and glycosically bound monoterpenes in developing Muscat grapes. J. Sci. Food Agric. 32, 919-924.

Wilson, B., Straus, C.R., Williams, P.J., 1986. The distribution of free and glycosidically bound monoterpenes among skin, juice and pulp fractions of some white grape varieties. Am. J. Enol. Viticult. 37, 107-111.

Winterhalter, P., Sefton, M.A., Williams, P.J., 1990. Volatile $C_{13}$-norisoprenoid compounds in Riesling wine are generated from multiple precursors. Am. J. Enol. Viticult. 41, 277-283.

Zoecklein, B.W., Marcy, J.E., Jasinski, Y, 1997. Effect of fermentation, storage sur lie on post-fermentation thermal processing of White Riesling (Vitis vinifera L.) glycoconjugates. Am. J. Enol. Viticult. 48, 397-402. 